\title{
THE EFFECT OF GARNISHEE ORDERS ON THE PERSONNEL OF THE DEPARTMENT OF HEALTH, SOUTH AFRICA
}

\author{
Kabelo Moloantoa, \\ Medicare Hospital, 271 Beyers Naude Street, Rustenburg, South Africa. \\ Mailing Address: P O Box 4982 Rustenburg, 0300. \\ email address: kabelomoloantoa@ymail.com
}

Florinda Taute,

Senior lecturer, University of Pretoria, South Africa

Mailing address: PO Box 1874, Wapadrand, Pretoria, 0050

Email address: florinda.taute@up.ac.za

\begin{abstract}
Employees are confronted with garnishee orders on a daily basis. This article presents the findings of a qualitative study designed to explore the effect of garnishee orders on personnel. The results indicated that employees viewed both internal and external factors as the reason for their financial difficulties and felt trapped by overindebtedness. This resulted in psycho-social and occupational maladjustments. The study also revealed that the participants' thought they would benefit from regular guidance and training in personal financial management.
\end{abstract}

KEYWORDS: Garnishee order, Garnishee attachment, Department of Health 
After the formal institutionalization of micro-lending in 1992, lenders, collectors and attorneys have found that garnishee orders constitute the most efficient mechanism for collection. Garnishee orders are more successful than debit orders, payroll deductions and cash deposits, and their implementation can be inexpensive (Legal Wise, 2010). The reliability and easy use of garnishee orders as a collection mechanism is best shown in the significant increase in garnishee orders (approximately a 67\% increase) in the public sector (Moaisi, 2013; Will the real garnishee stand up, 2004). The South African Government is concerned about the 216,857 public servants who made garnishee-related payments and the amount paid during 2006/2007, which suggests that a large number of public servants are over-indebted. The figure amounts to $20 \%$ of the total number of public servants employed in the Public Service in South Africa (Nyaruwata \& Leibbrandt, 2009; Public Service Commission, 2007).

High consumer debt levels are not unique to South African consumers, but affect consumers all over the world. The Reserve Bank of Australia noted an upward drift in the maximum permissible debt servicing ratio of $50 \%$ of gross income (Griffiths, 2007). In Sweden, the aggregate household indebtedness was reported to be slightly over $70 \%$ of GDP (Persson, 2008). According to The Nation (2010), published in Thailand, it was found that in $2010,84.1 \%$ of all civil servants were indebted, compared to $81.6 \%$ in 2006.

However, most published EAP studies have focused primarily on the effect of garnishee orders as reported by the employer (Boltz, 2009). Employers associate financial stress with several negative effects, such as impaired performance and effectiveness, reduced productivity, a diminished level of customer service, absenteeism, a decline in turnover, industrial accidents, alcohol and drug use and destructive behaviours (Van der Colff \& Rothmann, 2009). Only a limited number of studies have focused more directly on the exploration of the effect of garnishee orders on the employees. As they are relevant to 
this study, some of the psychological and physical effects of garnishee orders will be discussed, with specific focus on the employees and their families.

\section{DEFINITION OF CONCEPTS}

A garnishee order is an instruction by court to the debtor's employer to deduct, on a monthly basis, a specified amount from the debtor's salary or an amount of money owed by the debtor to a third party (American Payroll Association, 2011; Arde, 2012; Cobbert, 2004; Hahn \& Hahn Attorneys, [Sa]; Public Service Commission, 2007). The deduction requires the debtor's consent (Allwright, 2013; Roux, 2010).

Garnishee attachment is defined as:

an order issued by the court in favor of a judgment creditor attaching the garnishees at present, or in future, owing or accruing to the judgment debtor by or from his or her employer to the amount necessary to cover the judgment and the costs of the attachment (Public Service Commission, 2007).

The Department of Health is a state department rendering primary, secondary and tertiary health services to all the people of the Republic of South Africa (Diphoko, 2009). Mosue (2012) defines it as a division of a local or larger government responsible for the oversight and care of matters relating to public health.

\section{CONTEXTUALIZATION OF GARNISHEE ORDERS}

Until recently, the two most important acts governing credit law in South Africa were the Usury Act 73 of 1968 and the Credit Agreements Act 75 of 1980. However, in June 2006, the two acts were repealed to make way for the National Credit Act 34 of 2005. The act codifies a number of basic consumer rights regarding the credit market. 
Previously, certain consumers, especially the illiterate, were unjustifiably exploited (Allwright, 2013; Roux, 2010).

A creditor who has not been paid has the right to apply to a magistrate to have the income, money or property of the debtor attached into the possession of the debtor or another person (Calcadot, 2009). If a salary or an income is involved, the order is known as a garnishee attachment order, which exists in terms of Section $65 \mathrm{~J}$ of the Magistrates' Court Act 32 of 1944.

A garnishee order is initially experienced with shock and anxiety, and a sense of entrapment and confusion (Taylor, Gooding, Wood \& Tarrier, 2011). If an employee does not seek psychological help, it may lead to changes in affect, a lack of interest in pleasurable activities, avoidance of social contact, thought disturbances, poor hygiene, self-loathing (Eyers \& Parker, 2010) and ultimately depression (Harrisberg, 2008). The experience of personal responsibility for over-indebtedness and the negative outcomes (garnishee orders) may yield maladaptive guilt that could be predicted to show robust links to psychological maladjustment, including depressive symptoms (Kim, Thibodeau \& Jorgensen, 2011).

Financial problems are perceived as personal failures in a society that places a high premium on success and possessions. Economic stress can have a negative psychological and social impact on employees and families (Boltz, 2009; Pilgrim, 2009). There seems to be a correlation between economic stress and increased levels of anxiety, stress, depression somatic complaints, anger, poor health and lowered selfesteem. Financial stress thus aggravates the possibility of illnesses such as hypertension, migraine, headaches, insomnia, ulcerative colitis, diabetes, herpes and multiple sclerosis (Hitt, Miller \& Colella, 2006; Howe, Hornberg, Weihs, Moreno \& 
Neiderhiser, 2012; Nakao, 2010; Soffer-Dudek \& Shahar, 2011; Stachowiak, 2012; Vogel, 2006; Zastrow, 2004). When employees are exposed to the stress of having their salary attached for a long time, they are overwhelmed. They have reduced energy, which results in exhaustion (Coopmans, 2007) and become susceptible to health problems (Vogel, 2006).

In 2008, global economies witnessed one of the most dire impacts of unsound credit extension policies the world has ever experienced (Nicolson, 2012). The collapse of sub-prime mortgages in the United States of America (USA) caused extensive losses on financial markets and shook the very foundations of the global banking industry (American Payroll Association, 2011). The crisis placed the international spotlight on unsustainable credit extension, which had been of concern to the South African government and other role players for some time (Department of Finance, 2012). The South African Reserve Bank's Monetary Policy Committee has expressed continued concern over the levels of consumer indebtedness (Chapman, 2009; Kiyosaki, 2006; Le Roux \& Douglas, 2010; Rossouw, 2008) according to the country's high household debt-to-income ratio (Duncan, 2012).

\section{RESEARCH METHODOLOGY}

\section{Research Design}

The researchers used a qualitative research design to explore the phenomenon of garnishee orders so as to understand the effect on the personnel of the Department of Health, North West Province, Rustenburg Sub-District (Crankshaw, 2005; Payne \& Payne, 2004; Yin, 2011). A collective case study furthered understanding of the garnishee orders and their effect on the personnel, as the individual cases of 10 
volunteer participants were studied extensively (Christensen, 2007; Creswell, 2009; Fouché, 2005; Greeff, 2005; Kotzab, Seuring, Muller \& Reiner, 2005).

The population is comprised of the 49 personnel of the Department of Health, Rustenburg Sub-District, with the specific characteristic of garnishee orders against their salaries (Keppel, 2009; Strydom, 2005). The Rustenburg Sub-District is divided into five clusters: Boitekong, Bafokeng, Thabane and Marikana and the Sub-District's head office.

\section{Participants}

Non-probability sampling was selected for the study, whereby the probability of each person being drawn into a sample was not known (Strydom, 2005). In order to have the participants who would yield the most relevant and plentiful data in the study, the researchers used volunteer sampling to identify and target the employees who had garnishee orders against their salaries (Davies, 2007; Yin, 2011). The Human Resources (HR) Department identified relevant employees and communicated with them about the study to see whether they were willing to participate. Employees who gave permission were then referred to one of the researchers for further briefing on the intended study. The HR manager ensured that the personnel with garnishee orders were aware of the study, and the first two from the five clusters to volunteer formed part of the sample of ten participants. The first two volunteers from each of the five clusters were selected after being made aware of the study by the HR manager. 


\section{Data Collection}

In order to study the phenomenon of garnishee orders, semi-structured interviews were the predominant mode of data collection. Interviews are deeply and unavoidably implicated in creating meanings that ostensibly reside within participants (Greeff, 2005). One of the researchers conducted one-on-one interviews because he could directly observe the employees' behaviour and feelings, and discern how personnel interpreted the fact that their salaries had been attached (Creswell, 2009).

The participants had the opportunity of sharing their stories, passing on their knowledge, and providing their own perspective on garnishee orders. A set of predetermined questions stated on an interview schedule was used, but the interview was guided rather than dictated by the schedule. The participants were regarded as the experts on

the subject and were therefore allowed maximum opportunity to tell their stories. The advantage of the semi-structured interview was its opportunity to gather the intended data and the ability to provide the interesting and unexpected data that emerged (O'Leary, 2010).

The interviews took place in the consulting room at the clinic of the Department of Health, Rustenburg Sub-District, during the participants' lunch breaks, in order not to disrupt their normal daily occupational activities. The interviews took place in the last quarter of 2012 and the first quarter of 2013 . They lasted for approximately one hour, and were tape-recorded for accuracy, because not everything could be written down. In fact, the researchers were not certain what was important enough to be written down, so both the tape recorder and the manuscripts were used (Bui, 2009; Merriam, 2009). 
Every possible precaution was taken during the interviews to explain the objectives and background of the study, and questions were structured in such a way that there was no prejudice against or bias towards the participants (De Vos, 2005).

\section{Reliability}

The reliability of the information was determined by assessing the congruency and consistency in the responses (Maree \& Van der Westhuizen, 2007; Pietersen \& Maree, 2007). This was determined by ascertaining whether there were responses manifesting two different themes in one response. Constructive confrontation, reassurance, probing, paraphrasing and re-asking the same question at different times were used to tackle the issue of reliability and the validity of the responses. The researcher also took into account his own judgment and feelings on the effect of garnishee orders so that these would not influence the data (Babbie, 2004).

\section{Data Analysis}

The researcher began the task of making sense of the data by consolidating, reducing and interpreting what the respondents said about garnishee orders (Merriam, 2009). In analyzing data, the researcher was guided by Creswell's analytical spiral (1968) as stipulated by De Vos (2005), which involves planning and recording data, data collection and preliminary analysis, managing and organizing data, reading and writing memos, generating categories, themes and patterns, coding the data, testing the emergent understanding, searching for alternative explanations and representing and visualizing. The steps were not followed rigidly, as some were interrelated and could occur 
simultaneously (Creswell, 2007). In this study the qualitative research does not support evidence of causality.

\section{IDENTIFICATION OF THEMES AND SUB-THEMES}

De Vos (2005) maintains that "identifying themes, recurring ideas or language patterns of beliefs that link people and settings is the most intellectually challenging phase of data analysis" (p. 338). All the analyses were conducted by generating themes and subthemes contained in the participants' responses. Information gathered from the main study is categorized into the following themes and sub-themes presented in the table below.

Table1: Summary of identified themes on the effect of garnishee orders on the personnel of the Department of Health, South Africa

\begin{tabular}{|c|c|}
\hline Themes & Sub-themes \\
\hline \multicolumn{2}{|l|}{ Understanding the garnishee orders process } \\
\hline Reasons for garnishee orders & $\begin{array}{l}\text { Poor budgeting } \\
\text { Micro lenders } \\
\text { Social causes } \\
\text { Intra-personal factors }\end{array}$ \\
\hline The effects of garnishee orders on the employee & $\begin{array}{l}\text { Social effects } \\
\text { Psychological effects } \\
\text { Emotional effects } \\
\text { Physical effects }\end{array}$ \\
\hline The effects of garnishee orders on the employer & $\begin{array}{l}\text { Absenteeism } \\
\text { Low morale and motivation } \\
\text { Substance abuse }\end{array}$ \\
\hline Active management involvement & \\
\hline
\end{tabular}




\section{THEME 1: UNDERSTANDING THE GARNISHEE ORDER PROCESS}

The first theme identified was the participants' knowledge of the process whereby the garnishee order is obtained by the judgment creditor. The participants indicated their lack of knowledge of the process by making statements like the following:

To tell you the honest truth, I do not understand anything about the garnishee order, I only got told that so and so has garnished me........... do not have an understanding of the process of a garnishee order apart from the fact that it occurs as a result of lack of payment of debts.... I only know that a garnishee order occurs when the debtor fails to service his/her loan.

The participants were unable to provide a detailed description of how the creditor obtained the authorization to garnish his/her salary, as stipulated by the University of Pretoria Law Clinic (2008).

\section{THEME 2: REASONS FOR GARNISHEE ORDERS}

The second theme identified was the reasons for garnishee orders. Poor budgeting, low salary, micro-lenders, inter-personal influence, social causes and intra-personal factors were identified as the sub-themes.

\section{Sub-Theme 1: $\quad$ Poor budgeting}

Participants felt it was their poor financial planning that had resulted in their salary attachment by responding as follows. 
When I see something interesting I just go ahead and make a purchase without first evaluating if I can afford it.............. I take out loans of about four year repayment terms and before the end of the year I take out another loan. The loans then pile up and make it difficult to repay them..........Competing with the neighbors contributes to my poor budgeting.

From the above excerpt, it is clear that participants concurred that poor financial planning had resulted in over-indebtedness. This excerpt corroborates the perspective by Persse (2007), who indicates that employees fail to determine realistic financial goals. Employees are thus impulsive and ill-disciplined when making their purchase decisions and can be psychologically or environmentally driven (Du Plessis, Strydom \& Jooste, 2012).

\section{Sub-theme 2: Micro-lenders}

The participants agreed that micro-loans offered immediate relief and rescue from their financial needs but also meant the long-term difficulties of over-indebtedness. The following statement is an indication of responses by the participants.

Micro-lenders are the cause of my financial problems...........At the end of the year I had already made three micro-loans and could not service the debt............ I borrow money from micro-lenders without planning because I want to maintain my children and the extended family. 
The high repayment interest owing to micro-lenders resulted in the participants' inability to service their loans. The participants ultimately ignored this and avoided repaying the loans until their salary was attached. The responses concur with Mount, llies and Johnson's (2006) opinion that employees deny that they have loans to repay.

\section{Sub-theme 3: $\quad$ Social factors}

It was interesting to note that participants regarded social factors as having resulted in their salary attachments. The following participant's statement makes this clear.

IIInesses in the family and other social functions that I cannot avoid.........My husband's negligence and poor use of money.......My child pressurizes me to meet the standard of his friends.......I want to live a descent life and as a result, I ended up buying things I cannot afford just to meet the expected social standard..........In order to maintain my social status, I have at least four micro lenders that I owe..........I buy designer clothes as a way to meet the standards of my colleagues.

The above extract supports that the participants changed their behavior, beliefs and thinking to align themselves with other people, to appease the group and gain approval from the members. The need to belong caused the participants to conform in order to be liked and accepted by their colleagues and the community (Radmanovic, 2008). 


\section{Sub-theme 4: Intra-personal factors}

Character challenges contributing to financial difficulties and ultimate garnishee orders were identified. The following is a participant's response illustrating the sub-theme of intra-personal factors.

I failed myself..... I know it is wrong but I do it anyway....... I do not have any other options.......... incur debts because of my inability to postpone needs......... I want to have enough money and spend it as I wish even though on the other side I know that I have debts.

The above statement indicates that the participant concurred with Sen (2011), who maintains that people with distorted self-images are easily influenced by others' opinions.

\section{THEME 3: THE EFFECTS OF GARNISHEE ORDERS ON THE EMPLOYEE}

The third theme identified was the participants' perspective on the effect of salary attachment. Their views on this were divided into four sub-themes indicating the social, psychological, emotional and physical effects.

\section{Sub-theme 1: Social effects}

When an employee receives a salary attachment, his/her social functioning is affected because of the decreased income. The following statement is an indication of the participant's response. 
Causes conflict at home, particularly with my wife........ am unable to meet the needs of my family..........At home it is worse and there is no life as I am continually fighting with my children..........Most people in the village call me a beggar...........Sometimes I wish I was not married and did not have children.........My wife left me due to my financial difficulties......As a result of the loans I become unable to afford to pay for accommodation, school fees, transport, social clubs, illnesses and funeral schemes.

It can be deduced that participants experienced feelings of hopelessness, survival difficulty and a decline in their relationships as the dominant social effects of the garnishee orders. This corroborates statements by Zastrow (2004) and Boko (2011) that financial difficulties result in family adjustment problems.

\section{Sub-theme 2: $\quad$ Psychological effects}

The following statement by a participant confirms Pilgrim's (2009) views that economic stress can have a negative psychological impact on employees.

It is a nightmare to live with a garnishee order, there is no way out of garnishee........Garnishee tarnishes my dignity........At one point I developed feelings that I was scared I might hurt my baby.......... It creates a lot of stress and I become irritable towards my wife and kids....... I started becoming involved in sexual indiscretions and regard sex as just a means for survival.... I was diagnosed with depression as a result of financial difficulties and was admitted to a psychiatric hospital for a period of three weeks. 
The above response confirms the opinion of Taylor et al. (2011), who maintain that employees experience a feeling of defeat and entrapment. The authors continue that employees often show discouragement and physical, psychological and socially destructive behaviors.

\section{Sub-theme 3: $\quad$ Emotional effects}

A garnishee order can initially be met with shock and anxiety, followed by a feeling of defeat, entrapment and confusion, as indicated by the following response by a participant.

I blame myself...... I regret it every time I take out a loan, I really cannot believe it.......It brings shame, guilt and sadness........It makes me feel mad..........It is very painful to have a salary attachment.....I started feeling very down, miserable, stressed, confused and frustrated.

The above response demonstrates the common symptoms of emotional exhaustion, feelings of unease and chronic worry (Boswell, Olson-Buchanan \& LePine, 2004).

\section{Sub-theme 4: Physical effects}

Participants experienced an inability to adjust physically to the demands of garnishee orders, as the following statement indicates.

My sugar level is too high and I have hypertension due to financial stress...I have migraine headaches and bodily pains since my salary was attached.....I 
developed uncontrollable gynecological complications due to financial stress........ started to self-medicate with Panado syrup and Allergex.......I experienced palpitations, rapid heartbeat, heat and coldness sensations and a fear of losing my mind. The garnishee order has made me lose hope in life..... It can be comparable to a loss of a family member because you weep uncontrollably, have poor sleeping patterns, poor appetite, general body pains, tinnitus, fatigue, a need to be alone and feelings of irritability.

This correlates with the view by Hitt, Miller and Colella (2006) that the employee becomes susceptible to physical health problems as a result of financial difficulties.

\section{THEME 4: THE EFFECTS OF GARNISHEE ORDERS ON THE EMPLOYER}

The fourth theme identified from the data collected revealed the effects of garnishee orders on the organization. Within theme four, the following sub-themes were identified: absenteeism, low morale and motivation and substance abuse.

\section{Sub-theme 1: $\quad$ Absenteeism}

Employee absenteeism is a worldwide phenomenon (Garnishee Audit Services, 2012; Human Potential Accounting, 2009). It is a costly yet poorly understood organisational phenomenon (Langenhoff, 2011). The following indicates the participant's response to a garnishee order.

On the fifteenth of the month (pay day) I make sure that I am not at work......It affects my work as a result of my absence.......My absence 
creates conflict with colleagues....... I consulted the doctor who booked me off for about a week........At times I do not come to work.......I stopped going to work when I realised that I was earning less than a R1000 on my salary due to my attachment order.... have been on temporary disability leave for the past four months.

This concurs with Paul's (2008) finding that employees lack the motivation to go to work after receiving a salary attachment, perceiving that their absence from work has little impact on things like employee morale, cost, production and customer satisfaction.

\section{Sub-theme 2: $\quad$ Low morale and motivation}

The following statement by a participant indicates that employees who had garnishee orders often experienced decreased morale and motivation, which affected their colleagues.

I only work to survive for that month but I have no plans that in future I might buy a house or a car......... I think about the problems daily without seeing a solution......... On a pay day I sometimes sleep while on duty, especially when thinking about money........... I started to hate my job.

This concurs with Bhaga's (2010) opinion that receiving a garnishee order results in poor overall work performance. 


\section{Sub-theme 3: $\quad$ Substance abuse}

The participants acknowledged the danger signs relating to alcohol abuse due to their financial problems.

If I had no children, I would be dead or I would be an alcoholic....... abuse alcohol to help me sleep and to be happy.... go to work drunk to relieve myself of the stress, particularly on pay day.

The above response demonstrates that financial stress has several negative effects, such as alcohol and drug usage and destructive behaviors (Boltz, 2009). It is clear from the response that the participant viewed alcohol as something that would help regulate a negative emotional state (Jahng, Solhan, Tomko, Wood, Piasecki \& Trull, 2011; Mata, Thompson, Jaeggi, Buschkuehl, Jonides \& Gotlib, 2012).

\section{THEME 5: ACTIVE INVOLVEMENT BY MANAGEMENT}

The last theme identified in data collection was the participants' recommendations on the management of garnishee orders.

Management should appoint a financial advisor........ There needs to be inservice training by the state accountants for employees, the HR officers and the labour relations officers regarding financial issues of employees..... The department should send a financial adviser to help the employees regarding the right way of using money. 
Participants felt that there should be a financial management programme which could be used as a point of reference. The participants' needs emphasized the significance of introducing the employees of BMW to a Financial Wellness Programme, where they achieved a total debt reduction of $57 \%$ and a $50 \%$ reduction in creditors (Procare, 2009).

\section{CONCLUSIONS}

This study explored the effects of garnishee orders on the personnel of the Department of Health, Rustenburg, Sub-District, South Africa. Analysis of the data revealed the following:

Employees revealed a considerable lack of factual information or detailed description when it came to how the creditor obtained authorization for garnishing someone's salary. However, they had a clear understanding of how things like poor budgeting, involvement with micro-lenders, social causes and intra-personal factors ultimately led to the attachment of their salaries. The employees also agreed that micro-loans offered immediate relief and rescue from their financial needs, but also meant the long-term difficulties of over-indebtedness.

Receiving a garnishee order had a negative effect on the employees' mental well-being, physical health and social abilities, as they experienced guilt and shame about natural personal drives or impulses. Garnishee orders also impacted negatively on the organization, as employees were often absent, they struggled with low morale and motivation and often abused alcohol to limit the effect of their garnishee orders. 
It is thus important for management to understand the effect of garnishee orders on the employee and the employer. They must also understand how to facilitate the process of financial management in the workplace. Proper management of employees' salary attachments is an indication that an organization is keeping track of its own affairs. As shown already, the garnishee order is not only about employee financial difficulties but also includes factors such as operational disruption. Since Human Resources practitioners are at the forefront of managing the garnishee orders, they should ideally be thoroughly trained in dealing with this process as and when it occurs. The HR practitioners will thus be equipped to provide in-service training for employees on financial issues.

It is critical to mention that the present study was exploratory. There is a dearth of literature and studies conducted in South Africa. In addition, it is of paramount importance to note that the findings and implications of this study need not be regarded as conclusive, but should be seen as an indication that the issue of garnishee orders requires further research.

\section{RECOMMENDATIONS}

The following recommendations are made as possible guidelines for managing overindebtedness and garnishee orders in South Africa.

Employees should undergo training to improve their financial management skills. The training should be initiated during the induction process and should be a continuous process. It is through training that managers will be able to create a climate in the 
workplace that will enable employees to improve their financial decision-making skills. HR practitioners should be informed on the legislation and their role as far as garnishee orders are concerned. Regular surveys should be conducted to establish the financial positions of employees. The HR department should provide financial well-being and literacy workshops to create employee awareness of proper financial management and the employees who were not in debt must be helped to stay out of debt and avoid garnishee orders at all cost. Investigation and advocacy is vital, the EAP should make a presentation in every department and in every province. Finally, countries should consider the establishment of employee assistance programmes with key focus on proper legislative framework on micro-lending, a procedure for the issuing of garnishee orders, and on educating employees on their credit rights, budgeting, borrowing and saving, and on how to manage these effectively. In countries were garnishee orders are allowed, regulations should be made by the employer to verify how the court order had been obtained.

\section{LIMITATIONS OF THE STUDY}

One of the challenges in compiling the study was that the phenomenon of the effect of garnishee orders on the employee is poorly researched and available data rather focuses on effects of garnishee orders on the organisation.

\section{RECOMMENDATIONS FOR FURTHER RESEARCH}

It can be said that the subject of garnishee orders will continue to be an issue for debate, especially where its impact on employee performance is involved. Unfortunately 
it seems that many researchers are concentrating on the effect of garnishee orders on work production and tend to forget the wider effects on the employee. As a result, too little progressive research on the subject is being conducted. Similar studies should be extended to include other public sectors in the Republic of South Africa or even internationally.

\section{REFERENCES}

Allwright, P. (2013). Garnishee orders: Continued abuse and exploitation. Paper presented at the debt summit. 11 January, Midrand, South Africa. Retrieved January 18, 2013, from http://www.hrfuture.net/daily-article/garnishee-on

American Payroll Association. (2011). Garnishment. Retrieved August 29, 2012, from www.americanpayroll.org/

Arde, A. (2012). Banks to stop using garnishee orders. Retrieved January 19, 2013, from www.iol.co.za/.../banks-tostop-using-garnishee-orders-1.1

Babbie, E. (2004). The practice of social research. $\left(10^{\text {th }}\right.$ ed.). Belmont: Wadsworth/Thomson Learning.

Bhaga, T. (2010). The impact of working conditions on the productivity of nursing staff in the midwife obstetrical unit of Pretoria West Hospital. Pretoria: University of Pretoria. (MSW Mini-Dissertation).

Boko, S. (2011). Children's experiences of trauma because of marriage conflict. Pretoria: University of Pretoria. (MA Mini-Dissertation).

Boltz, E. (2009). When Personal Finances Affect the Workplace: Employee Assistance Services Life Management Associates With you every step of the way. Retrieved June 09, 2013, from www.Imaeap.com/articles/personal finances.php

Boswell, W.R., Olson-Buchanan, J.B. \& Le Pine, M.A. (2004). Relations between stress and work outcomes: The role of felt challenge, job control, and psychological strain. Journal of vocational behavior, 64(1), 165-181.

Bui, Y.N. (2009). How to write a master's thesis. London: Sage Publications. 
Calcadot, C. (2009). Garnishee order. Retrieved February 02, 2009, from http://www.calcadot.co.za/forum/personalincome/146-garnishee-orders-need-more

Chapman, G. (2009). The marriage you've always wanted. Illinois: Moody Publishers.

Christensen, L.B. (2007). Experimental methodology. (10 ${ }^{\text {th }}$ ed.). Boston: Pearson.

Cobbert, J. (2004). Avoid the alluring debt trap. Personal Finance, 330(293), 8-9.

Coopmans, J.W.M. (2007). Stress related causes presenteeism amongst South African managers. Pretoria: Gordon Institute of Business Science, University of Pretoria. (MBA Mini-Dissertation).

Crankshaw, H. (2005). Personal financial planning: Strategies for successful practice management. Pretoria: University of Pretoria. (MBA Dissertation).

Credit Agreements Act 75 of 1980 (Published in Government Gazette, (33487) Pretoria: Government Printer).

Creswell, J.W. (2009). Research design: Qualitative, quantitative, and mixed methods approaches. (3 ${ }^{\text {rd }}$ ed.). Los Angeles: Sage Publications.

Davies, M.B. (2007). Doing a successful research project: Using qualitative or quantitative methods. Houndmills: Palgrave MacMillan.

De Vos, A.S. (2005). Qualitative data analysis and interpretation. In A.S. De Vos, (Ed.), H. Strydom, C.B. Fouché \& C.S.L Delport. Research at grassroots for the social sciences and human services professions. (3 ${ }^{\text {rd }}$ ed.). Pretoria: Van Schaik Publishers.

Department of Finance. (2012). Implementation of North West Provincial Government cost containment policy. April 2012.

Diphoko, A.K. (2009). Interview with Clinical Operations Manager, Classic House Clinic. [Transcript]. 25 March. Rustenburg.

Du Plessis, P.J., Strydom, J.W. \& Jooste, C.J. (2012). Marketing management. (6 ${ }^{\text {th }}$ ed.). Cape Town: Juta.

Duncan, F. (2012). Why South Africans save so darn little: South Africa stands out among emerging nations for low savings. Moneyweb’s Personal Finance, 330(378), 1. 
Eyers, K. \& Parker, G. (2010). Tackling depression at work: A practical guide for employees and managers. London: Routledge.

Fouché, C.B. (2005). Qualitative research design. In A.S. De Vos, (Ed.), H. Strydom, C.B. Fouché \& C.S.L Delport. Research at grassroots for the social sciences and human services professions. ( $3^{\text {rd }}$ ed.). Pretoria: Van Schaik Publishers.

Garnishee Audit Services. (2012). Garnishee Orders and the potential risks to business. Retrieved August 24, 2012, from http://garnisheeauditservices.wozaonline.co.za/-garnishee+orders+and+the+impacto+on+yoccessed

Greeff, M. (2005). Information collection: Interviewing. In A.S. De Vos, (Ed.), H. Strydom, C.B. Fouché \& C.S.L Delport. Research at grassroots for the social sciences and human service professions. ( $3^{\text {rd }} \mathrm{ed}$.). Pretoria: Van Schaik Publishers.

Griffiths, M. (2007). Consumer debt in Australia: Why banks will not turn their backs on profit. International Journal of Consumer Studies, 31, 230-236.

Hahn \& Hahn Attorneys. [Sa]. Collection default. Retrieved October 12, 2012, from www.hahn.co.za/

Harrisberg, C. (2008). Laughing yourself stressless. Journal of the South African Institute of People Management, 26(10), 16.

Hitt, M.A., Miller, C.C. \& Colella, A. (2006). Organizational behavior: A strategic approach. Hoboken: John Willey \& Sons, Inc.

Howe, G.W., Hornberg, A.P., Weihs, K., Moreno, F. \& Neiderhiser, J.M. 2012. Journal of Abnormal Psychology, 121(2), 325-338.

Human Potential Accounting. (2009). Employee debt- Personal finance employee education. Retrieved June 17, 2010, from www.personalfinancefoundation.org/.../UK-Employee-Debt-Expert

Jahng, S., Solhan, M.B., Tomko, R.I., Wood, P.K., Piasecki, T.M. \& Trull, T.J. (2011). Affect and alcohol use: An ecological momentary assessment study of outpatients with borderline personality disorder. Journal of Abnormal Psychology, 120(3), 572-584.

Keppel, S. (2009). Introduction to design and Analysis. Retrieved March 11, 2009, from http://psy.standrews.ac.uk/resources/glossary.shtl 
Kim, S., Thibodeau, R. \& Jorgensen, R.S. (2011). Shame, guilt, and depressive symptoms: A meta-analytic review. Psychology Bulletin, 137(1), 68-96.

Kiyosaki, K. (2006). Rich woman: A book on investing for women. New York: Rich Press.

Kotzab, H., Seuring, S., Muller, M. \& Reiner, G. (Eds.). (2005). Research Methodologies in supply chain management. New York: Physica-Verlag.

Langenhoff, W. (2011). Employee absenteeism: Construction of a model for International comparison of influential determinants. Rotterdam: Erasmus University. (MSC Dissertation).

Le Roux, W. \& Douglas, L. (2010). 365 things every woman should know. Illinois: Christian art gifts.

Legal Wise. (2010). Asikhulume, The peace of mind newsletter. November 2010.

Magistrates' Court Act 32 of 1944 (Published in the Government Gazette, (919) Pretoria: Government Printer).

Maree, K. (Ed.), \& Van der Westhuizen, C. (2007). Planning a research proposal. In J.W. Creswell, L. Eberson, I. Eloff, R. Ferreira, N.V. Ivankova, J.D. Jansen, J. Nieuwenhuis, J. Pietersen, V.L. Plano Clark \& C. Van der Westhuizen. First steps in research. Pretoria: Van Schaik Publishers.

Mata, J., Thompson, R.J., Jaeggi, S.M., Buschkuehl, M., Jonides, J. \& Gotlib, I.H. (2012). Walk on the bright side: Physical activity and affect in major depressive disorder. Journal of Abnormal Psychology, 121(2), 297-308.

Merriam, S.B. (2009). Qualitative research: A guide to design and implementation. San Francisco: Jossey-Bass.

Moaisi, L. (2013). Consumer debt level of the Department of Health Public Servants in Mahikeng. Pretoria: (MBM Mini-Dissertation).

Mosue, O. (2012). Interview with Labor Relations Officer, Rustenburg Sub-District Health Department. [Transcript]. 12 June. Rustenburg.

Mount, M., Ilies, R. \& Johnson, E. (2006). Relationship of personality traits and counterproductive work behaviors: The mediating effects of job satisfaction. Personnel Psychology, Journal of Applied Research, 59(3), 591-622.

Nakao, M. (2010). Work-related stress and psychosomatic medicine. Journal of Work Environ Health, 4(4), 36-49.

National Credit Act 34 of 2005 (Published in the Government Gazette, (28893) Pretoria: Government Printer). 
Nicolson, G. (2012). Garnishee Orders. Retrieved July 17, 2012, from dailymarverick.co.za/article/18April2012

Nyaruwata, G. \& Leibbrandt, M. (2009). Personal debt and financial access: Analysis of the NIDS Wave 1 Dataset. Discussion paper no. 8, National Income Dynamics Study. Cape Town.

O'Leary, Z. (2010). The essential guide to doing your research project. California: Sage Publications.

Paul, G.W. (2008). Absenteeism management at Willard Batteries. Port Elizabeth: Nelson Mandela Metropolitan University. (MA Mini-Dissertation).

Payne, G. \& Payne, J. (2004). Key Concepts in Social Research. New Delhi: Sage Publications.

Persse, J. (2007). Project management success with CMMI: seven CMMI process areas. Montreal: Prentice Hall.

Persson M. (2008). Household indebtedness in Sweden and implications for financial stability. BIS Papers 46, 124135.

Pietersen, J. \& Maree, K. (Eds). (2007). Standardisation of a questionnaire. In J.W. Creswell, L. Eberson, I. Eloff, R. Ferreira, N.V. Ivankova, J.D. Jansen, J. Nieuwenhuis, J. Pietersen, V.L. Plano Clark, \& C. Van der Westhuizen. First steps research. Pretoria: Van Schaik Publishers.

Pilgrim, D. (2009). Key Concepts in mental health. (2 ${ }^{\text {nd }}$ ed.). Los Angeles: SAGE.

Procare. (2009). Financial problems and debt becoming a nightmare. Retrieved May 17, 2012, from www.procare.co.za/finincial.html

Public Service Commission. (2007). Report on the indebtedness of public servants. November.

Radmanovic, M. (2008). The evaluation of emotional intelligence competencies from the customer perspective. Pretoria: Gordon Institute of Business Science, University of Pretoria. (MBA Dissertation).

Rossouw, Z. (2008). The impact of the National Credit Act on micro lending sales in a bank in South Africa. Pretoria: Gordon Institute of Business Science, University of Pretoria. (MBA Dissertation).

Roux, K. (2010). Garnishee orders and the law-know your rights. Retrieved August 15, 2011, from kayladumigtown.wordpress.com/tag/Kayla-roux/

Sen, N. (2011). Resolving Your Inner Conflicts. Retrieved March 23, 2013, from www.calmdownmind.com/resolvingyour-inner-conflicts 
Soffer-Dudek, N. \& Shahar, G. (2011). Daily stress interacts with traits dissociation to predict sleep-related experiences in young adults. Journal of Abnormal psychology, 120(3), 719-729.

Stachowiak, J. (2012). A strategy to maintain control of your finances and your life. Retrieved July 12, 2013 , from http://ms.about.com/od/livingwellwithms/a/Plan-For-Financial-Independence-With-Multiple-Sclerosis.htm

Strydom, H. (2005). Sampling and sampling methods. In A.S. De Vos, (Ed.), H. Strydom, C.B. Fouché \& C.S.L Delport. Research at grassroots for the social sciences and human service professions. ( $3^{\text {rd }}$ ed.). Pretoria: Van Schaik Publishers.

Taylor, P.J., Gooding, P., Wood, A.M. \&Tarrier, N. (2011). The role of defeat and entrapment in depression, anxiety, and suicide. Psychology Bulletin, 137(3), 391-420.

The Nation. (2010). Fair pay is one way to root out corruption. Retrieved May 17, 2013, from http://www.nationmultimedia.com/home/2010/09/16/ opinion/Fair-pay-is-oneway-

to-root-out-corruption-30138051.html

University of Pretoria Law Clinic. (2008). The incidence of and the undesirable practices relating to garnishee orders in South Africa. Pretoria: University of Pretoria.

Usury Act 73 of 1968 (Published in the Government Gazette, (22801) Pretoria: Juta \& Company).

Van der Colff, J.J. \& Rothmann, S. (2009). Occupational stress, sense of coherence, coping, burnout and work engagement of registered nurses in South Africa. South African Journal of Industrial Psychology, 35(1), 1-10.

Vogel, F.R. (2006). Stress in the workplace: the phenomenon, some key correlates and problem solving approaches. Pretoria: University of Pretoria. (DPhil Thesis).

Will the real garnishee stand up. 2004. Retrieved February 02, 2009, from http://www.qlink.co.za/qlhome/eao.html

Yin, R.K. (2011). Qualitative research from start to finish. London: The Guilford Press

Zastrow, C. (2004). Introduction to Social work and social welfare: empowering people. (8 ${ }^{\text {th }}$ ed.). Toronto: Thomson Brooks/Cole. 